\title{
An account on the non-malacostracan crustacean fauna from the inland waters of Crete, Greece, with the synonymization of Arctodiaptomus piliger Brehm, 1955 with Arctodiaptomus alpinus (Imhof, 1885) (Copepoda: Calanoida)
}

\author{
Federico Marrone ${ }^{1,}$, , Giuseppe Alfonso ${ }^{2}$, Fabio Stoch ${ }^{3}$, Valentina Pieri ${ }^{4}$, Miguel Alonso ${ }^{5}$, \\ Michalis Dretakis $^{6}$ and Luigi Naselli-Flores ${ }^{7}$
}

${ }^{1}$ Department of Biological, Chemical and Pharmaceutical Sciences and Technologies - Section of Zoology, University of Palermo, via Archirafi 18, 90123 Palermo, Italy.

2 Di.S.Te.B.A., University of Salento, s.p. Lecce-Monteroni, 73100 Lecce, Italy.

${ }^{3}$ Evolutionary Biology \& Ecology, Université Libre de Bruxelles, Avenue F.D. Roosevelt 50, 1050 Brussels, Belgium.

${ }^{4}$ University of Parma, Department of Chemistry, Life Science and Environmental Sustainability, 43124 Parma, Italy.

${ }^{5}$ Ecology Section, Department of Evolutionary Biology, Ecology and Environmental Sciences, Faculty of Biology, University of Barcelona, Avda. Diagonal 643, 08028 Barcelona, Spain.

${ }^{6}$ Natural History Museum of Crete, University of Crete, Knossos Av., P.O. Box 2208, 71409 Heraklion, Crete, Greece.

${ }^{7}$ Department of Biological, Chemical and Pharmaceutical Sciences and Technologies - Section of Botany and Plant Ecology, University of Palermo, via Archirafi 28, 90123 Palermo, Italy.

* Corresponding author: federico.marrone@unipa.it

Received: $15 / 02 / 18 \quad$ Accepted: $11 / 05 / 18$

\begin{abstract}
An account on the non-malacostracan crustacean fauna from the inland waters of Crete, Greece, with the synonymization of Arctodiaptomus piliger Brehm, 1955 with Arctodiaptomus alpinus (Imhof, 1885)

The Mediterranean bioregion is widely recognised as a biodiversity hotspot and its inland waters are among the species richest ecosystems of the northern hemisphere. However, the extent of such biodiversity has not been totally unravelled, especially in the Mediterranean islands. Here we present a first account of the crustaceans inhabiting 21 permanent and temporary ponds in Crete, the largest of the Greek islands and the fifth largest island in the Mediterranean Sea. The ponds, sampled between 2009 and 2018, cover all the island surface even though their number cannot be considered exhaustive to represent the entire non-malacostracan fauna of the island. Nevertheless, 46 taxa were identified and most of them are new records for Crete. Moreover, molecular taxonomy allowed to solve the systematic position of Arctodiaptomus piliger Brehm, 1955 and to synonymize this organism, previously considered endemic of the island, with Arctodiaptomus alpinus (Imhof, 1885). As regard branchiopods, this paper contributes a step ahead to clarify the taxonomic position of the Mediterranean Chirocephalus and Ceriodaphnia species. Finally, a review of all the non-stygobitic species present on the island is reported, including 78 taxa ( 21 Branchiopoda, 28 Copepoda and 29 Ostracoda). Overall, the achieved results offer new clues to solve the complex biogeographical pattern of the "entomostracan" crustaceans inhabiting the inland waters of the Mediterranean region.
\end{abstract}

Key words: Mediterranean biodiversity, temporary ponds, Calanoida, Branchiopoda, Ostracoda

\section{RESUMEN}

Listado de la fauna de crustáceos no malacostráceos de las aguas epicontinentales de Creta, Grecia, y sinonimización de 


\section{Arctodiaptomus piliger Brehm, 1955 con Arctodiaptomus alpinus (Imhof, 1885) (Copepoda, Calanoida)}

La bioregion mediterránea es ampliamente reconocida como un hotspot de biodiversidad, y sus aguas epicontinentales se encuentran entre los ecosistemas más ricos en especies del hemisferio septentrional. Sin embargo, el alcance de dicha biodiversidad aún no ha podido ser totalmente evaluado, especialmente en las islas mediterráneas. En el presente artículo se presenta una primera relación de los crustáceos no malacostráceos que habitan en 21 lagunas permanentes y temporales de Creta, la mayor de las islas griegas y la quinta más grande del mar Mediterráneo. Las lagunas, muestreadas entre 2009 y 2018, se encuentran distribuidas por toda la superficie de la isla aunque su número no puede considerarse lo suficientemente exahustivo como para representar a la totalidad de la fauna de crustáceos no malacostráceos de la isla. No obstante, se identificaron 46 taxones, la mayor parte de ellos nuevas citas para Creta. Además, la taxonomía molecular permitió solventar la posición taxonómica de Arctodiaptomus piliger Brehm, 1955 y sinonimizar este organismo, previamente considerado endémico de la isla, con Arctodiaptomus alpinus (Imhof, 1885). En lo referente a los branquiópodos, el presente artículo constituye un avance significativo para clarificar la posición taxonómica de las especies mediterráneas de Chirocephalus y Ceriodaphnia. Finalmente, se reporta una revisión de todas las especies no hipogeas de la isla que incluye 78 taxones (21 Branquiópodos, 28 copépodos y 29 ostrácodos). En conjunto, los resultados obtenidos ofrecen nuevas pistas para resolver el complejo patrón biogeográfico de los crustáceos "entomostráceos" que viven en las aguas epicontinentales de la region mediterránea.

Palabras clave: Biodiversidad mediterránea, lagunas temporales, Calanoida, Branchiopoda, Ostracoda

\section{INTRODUCTION}

Biodiversity in the Mediterranean Basin is amongst the highest recorded in any biogeographic region, both in terms of species richness and endemism (Blondel et al., 2010). This high diversity largely depends on the remarkable variability of the landscape and results from a complex combination of climatic, geological and paleogeographic factors which make the Mediterranean Basin a "hotspot" of biodiversity: i.e. a varied and fragmented mosaic of ecosystems and communities (Allen, 2001).

Some components of this Mediterranean environmental mosaic (e.g. terrestrial and marine flora, and vertebrate fauna) have been intensively studied in the past decades. However, natural freshwater ecosystems remain relatively unexplored habitat, especially as regard their "microscopic" biota. Although several man-made lakes are scattered all around the Mediterranean area, small water bodies and wetlands are undoubtedly the most characteristic aquatic ecosystems in the region (Alvarez Cobelas et al., 2005). Several thousands of small-sized water bodies (area $<0.001 \mathrm{~km}^{2}$ ) are located in Southern Europe (Meybeck, 1995) and they largely contribute to enhance regional biodiversity by hosting a number of species significantly higher than that present in large lakes (Downing, 2010), making Mediterranean small water bodies themselves "hotspots within hotspots" of biodiversity. More- over, freshwaters are among the most threatened ecosystems in the world because of anthropic pressure, i.e. industrialization of agriculture processes and urbanization (Dudgeon et al., 2006). Actually, since the importance of small water bodies has suffered a lack of scientific recognition in the second half of the past century, several wetlands and ponds have been drained and reclaimed. These actions have contributed to the rarefaction, at a very fast rate, of these freshwater ecosystems and their biota in all the Mediterranean Region (Zacharias \& Zampas, 2010; Stoch et al., 2016). The disappearing of freshwater ecosystems, coupled with the hydrological variability caused by climate change, the over-exploitation of water resources, and the changes induced in natural communities by the introduction of exotic species, highlights the urgency of biodiversity assessments in all the Mediterranean inland waters (Moreno et al., 2017). This is particularly true as regard the passively dispersed fauna inhabiting the inland waters of the Mediterranean islands and archipelagos. Actually, the success of dispersal for these species greatly depends on the number of ponds scattered across a given territory (Incagnone et al., 2015); the aquatic ecosystems on the islands acting as stepping-stones in the migration corridors of birds which transport resting stages and propagules across the Mediterranean Sea (Hindmarch $\&$ Kirby, 2002). Therefore, getting a knowledge as much as possible complete of the biodiversity 


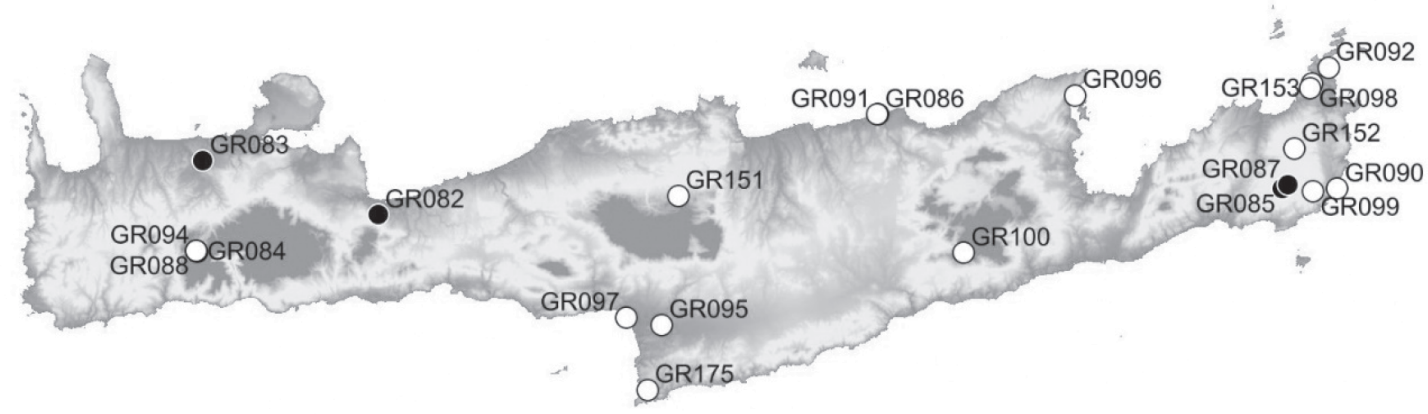

Figure 1. Location of the sampled sites. White circles: temporary waterbodies; black circles: permanent waterbodies. See table 1 for their names, codes, and coordinates. Situación de las localidades muestreadas. Círculos blancos: masas de agua temporales; círculos negros: lagos permanentes. En la tabla 1 se indican sus nombres, códigos y coordenadas.

of aquatic organisms in insular inland waters is of paramount importance to have a thorough vision on the biogeography of aquatic organisms in the Mediterranean region, and to develop sound conservation plans for these characteristic ecosystems (e.g. Alfonso et al., 2011; Bagella et al., 2016; Diaz-Paniagua, 2015; Grillas et al., 2004).

The crustacean fauna of aquatic ecosystems in the islands of the western Mediterranean Basin has been sufficiently documented, and several investigations were carried out in the last decades addressed toward the faunistic exploration of Sicily (Marrone \& Mura, 2006; Marrone et al., 2005, 2006a, 2006b; Pieri et al., 2006), Maltese islands (Lanfranco, 2001), Sardinia (Ruffo \& Stoch, 2005; Boix et al., 2017, and references therein), Corsica (Champeau \& Thiéry, 1990; Culioli et al., 2006) and Balearic Islands (Jaume, 1989-1990; Pretus, 1990; Zamora et al., 2005). Conversely, with the exception of Corfu (Stephanides, 1948), only a few, scattered data are available for the islands located in the eastern Mediterranean Sea (e.g. Mura \& Hadjstephanou, 1987; Tziortzis et al., 2014; Karagianni et al., 2018); remarkably, the availability of data for the Aegean Islands is very scarce.

In this paper, we provide a first faunal assessment of the non-malacostracan crustaceans inhabiting permanent and temporary ponds in Crete, the southernmost island of the Aegean archipelago and the fifth Mediterranean island by surface, with the aim to increase our knowledge on the biogeography of freshwater crustaceans passively dispersing across the Mediterranean Basin. To our knowledge, despite Crete has the highest amount of Mediterranean Temporary Ponds (priority habitat 3170 * according to the EU "Habitats Directive") among the administrative regions of Greece (Dimitriou et al., 2006), just a few papers dealing with Cretan inland water crustaceans are available in the scientific literature (see Kiefer, 1928; Chappuis, 1929, 1956; Klie, 1941; Brehm, 1955; Lindberg, 1956; Pesce \& Maggi, 1981; Petkowski et al., 2000). Moreover, with this paper we wish to commemorate the late Prof. Maria Rosa Miracle, who recently passed away after an illness of over one year. With her work, Maria Rosa largely contributed to establish a Mediterranean vision of Limnology and promoted the importance of Mediterranean small water bodies among dozens of students and colleagues.

\section{MATERIAL AND METHODS}

Crete, the largest island of Greece and the fifth in the Mediterranean Sea, is a limestone island covering an area of $8303 \mathrm{~km}^{2}$. It is located about $100 \mathrm{~km}$ south of the Greek mainland, and $175 \mathrm{~km}$ south-west of Turkey, along a line crossing the 
Table 1. List of the sampled sites. Geographical coordinates are expressed as decimal degrees (Map Datum: WGS84). GSD: "Greek Samples Database"; Hydr.: Hydroperiod; P: permanent; T: temporary. Relación de las localidades muestreadas. Las coordenadas geográficas se expresan en grados decimales (Datum: WGS84). GSD: "Greek Samples Database”; Hydr.: Hidroperiodo; P: permanente; T: temporal.

\begin{tabular}{|c|c|c|c|c|c|c|c|}
\hline $\begin{array}{l}\text { GSD } \\
\text { Code }\end{array}$ & $\begin{array}{l}\text { Latitudine } \\
\qquad \mathbf{N}\end{array}$ & $\begin{array}{c}\text { Longitudine } \\
\text { E }\end{array}$ & $\begin{array}{l}\text { Elevation } \\
\text { (m a.s.I.) }\end{array}$ & Habitat type & Hydr. & 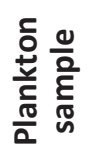 & 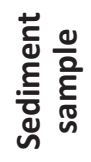 \\
\hline GR082 Limni Kourna & 35.329935 & 24.272689 & 16 & Lake & $P$ & $x$ & \\
\hline GR083 Limni Agya & 35.476936 & 23.932054 & 37 & Reservoir & $P$ & $x$ & \\
\hline GR084 Pond 1 at Omalos (Chania) & 35.324877 & 23.890936 & 1060 & Pond & $\mathrm{T}$ & $x$ & $x$ \\
\hline GR085 Pond along the Exo-Apidi road & 35.068422 & 26.124883 & 605 & Reservoir & $P$ & $x$ & \\
\hline GR086 Marsh 1 of Aposelemis & 35.334893 & 25.328806 & 0 & Ground pools & $\mathrm{T}$ & $x$ & \\
\hline GR087 Limni Zirou & 35.072129 & 26.137817 & 566 & Pond & $P$ & $x$ & \\
\hline GR088 Pond 2 at Omalos (Chania) & 35.326636 & 23.888916 & 1054 & Pond & $\mathrm{T}$ & $\mathrm{x}$ & $x$ \\
\hline GR090 Marsh of Xerocampos & 35.047924 & 26.237118 & 0 & Marsh & $\mathrm{T}$ & & $x$ \\
\hline GR091 Marsh 2 of Aposelemis & 35.335044 & 25.327582 & 0 & Marsh & $\mathrm{T}$ & & $x$ \\
\hline GR092 Marsh of Vai & 35.255259 & 26.264846 & 0 & Marsh & $\mathrm{T}$ & & $x$ \\
\hline GR094 Pond 3 at Omalos (Chania) & 35.325999 & 23.890255 & 1057 & Pond & $\mathrm{T}$ & & $x$ \\
\hline GR095 Faistos rock pool & 35.051189 & 24.814912 & 76 & Rock pool & $\mathrm{T}$ & & $x$ \\
\hline GR096 Spinalonga rock pool & 35.299204 & 25.738825 & 10 & Rock pool & $\mathrm{T}$ & & $x$ \\
\hline GR097 Limni Katalyki & 35.075107 & 24.745754 & 0 & Pond & $\mathrm{T}$ & & $x$ \\
\hline GR098 Athoudiaris pool & 35.235600 & 26.224500 & 558 & Mud puddle & $\mathrm{T}$ & & $x$ \\
\hline GR099 Karst pool & 35.051979 & 26.186606 & 539 & Pond & $\mathrm{T}$ & & $x$ \\
\hline GR100 Pond at Omalos (Dykti) & 35.071527 & 25.454529 & 1330 & Pond & $\mathrm{T}$ & $x$ & $x$ \\
\hline GR151 Stephana pond & 35.264155 & 24.893111 & 1128 & Mud puddle & $\mathrm{T}$ & $x$ & \\
\hline GR152 Karydi pool & 35.130936 & 26.164500 & 685 & Pond & $\mathrm{T}$ & $x$ & \\
\hline GR153 Profitis Ilias pool & 35.227659 & 26.219754 & 199 & Mud puddle & $\mathrm{T}$ & & $x$ \\
\hline GR175 Cape Lithinon rock pool & 34.945553 & 24.761992 & 152 & Rock pool & $T$ & $\mathrm{x}$ & \\
\hline
\end{tabular}


large islands of Karpathos and Rhodes. Cretan landscape is dominated by mountain ranges, with the highest peak reaching $2456 \mathrm{~m}$ a.s.l. and a mean elevation of $482 \mathrm{~m}$ a.s.1. The climate is typically Mediterranean at the low altitudes, but on the mountains snow coverage can easily persist until May, with bioclimatic belts ranging from the Thermomediterranean to the Supramediterranean one (Rivas-Martínez et al., 2004).

Crustacean samples were collected throughout the island from November 2009 to January 2018; the geographical coordinates and elevation of each site were recorded using a GPS, and an alphanumeric code referring to a "Greek Samples Database" (GSD) set up by FM and FS, was attributed to each of them (Fig. 1; Table 1). When water bodies were experiencing their inundated phase, a $200 \mu \mathrm{m}$ mesh-sized hand net was used to sample along shorelines, through submerged vegetation and in open waters, paying attention to collect crustaceans in all the microhabitats present in each sampled site. Collected crustacean samples were fixed in situ using $90 \%$ ethanol. Due to the different phenology of the species and to the seasonal succession of the crustacean assemblages of temporary waters, the presence of several taxa might be overlooked in sampling surveys with no or few temporal replicates; in such cases, the ex-situ re-hydration of dry sediment, known as "Sars' method" (van Damme \& Dumont, 2010), is a useful complement to the study of the actual crustacean diversity occurring in a given area. Accordingly, sediment samples were collected from most of the sampled water bodies and cultured in laboratory. About 300 gr of sediment were collected from each water body, integrating sediment samples from the deepest parts and the shores. When collected wet, the sediment was first dried at room temperature in open plastic bags. Sediment subsamples from each site were then rehydrated in laboratory using 4-litres plastic aquaria where a thin layer of sediment (about $5 \mathrm{~mm}$ ) was introduced with 3 litres of distilled water. Cultures were run at the University of Palermo during winter months and kept at temperature between 12 and $16{ }^{\circ} \mathrm{C}$ with a 12-hours photoperiod and a feeble aeration. Cultures were maintained for about two months and monitored each second day. The hatched crustaceans were collected monthly by filtering the water over a $125 \mu \mathrm{m}$ plankton net. Some specimens belonging to poorly-represented species in the cultures were individually collected by pipetting. The procedure described above was repeated four times and designated as "Hydration Experiments" 1-4 (Table S1, available at http://www.limnetica.net/en/limnetica).

Crustacean samples collected in the wild or coming from laboratory cultures were sorted in laboratory under a dissecting stereomicroscope. Branchiopods were identified according to Alonso (1996), Kotov \& Alonso (2010) and Sinev et al. (2012); copepods according to Dussart (1967, 1969), Kiefer (1971, 1978), Borutzky et al. (1991), Einsle (1993) and Ranga-Reddy (1994); ostracods according to Meisch (2000) and Mazzini et al. (2014).

Undissected crustacean specimens were stored in $95 \%$ ethanol at $-20{ }^{\circ} \mathrm{C}$, dissected soft parts were stored in glycerol in sealed microscope slides, and ostracod valves were dried and stored in micropaleontological slides.

Voucher specimens of Arctodiaptomus alpinus (Imhof, 1885) from GR088 (MZUF634) and GR100 (MZUF635), and Chirocephalus diaphanus from GR094 (MZUF637) and GR099 (MZUF636), were deposited in the Museo di Storia Naturale, Sezione di Zoologia “'La Specola", Università di Firenze, Italy (MZUF); other specimens are currently stored in FM's collection at the Dipartimento di Scienze e Tecnologie Biologiche, Chimiche e Farmaceutiche of the University of Palermo, Italy, and are available for loan on request.

Because of the unsettled systematics of the large branchiopod genus Chirocephalus and, in particular, of the species attributed so far to the $C$. diaphanus-group sensu Brtek (1995), two specimens of Chirocephalus diaphanus s.l. from sites GR084 and GR099 (Crete, Greece) were studied by amplifying and sequencing a fragment of the mitochondrial gene encoding for the cytochrome oxidase subunit I (COI), a molecular marker widely used in the molecular systematics and phylogeography of Chirocephalus (e.g.: Ketmaier et al., 2012; Reniers et al., 2013; Zarattini et al., 2013; Cottarelli et al., 2017). Comparative 


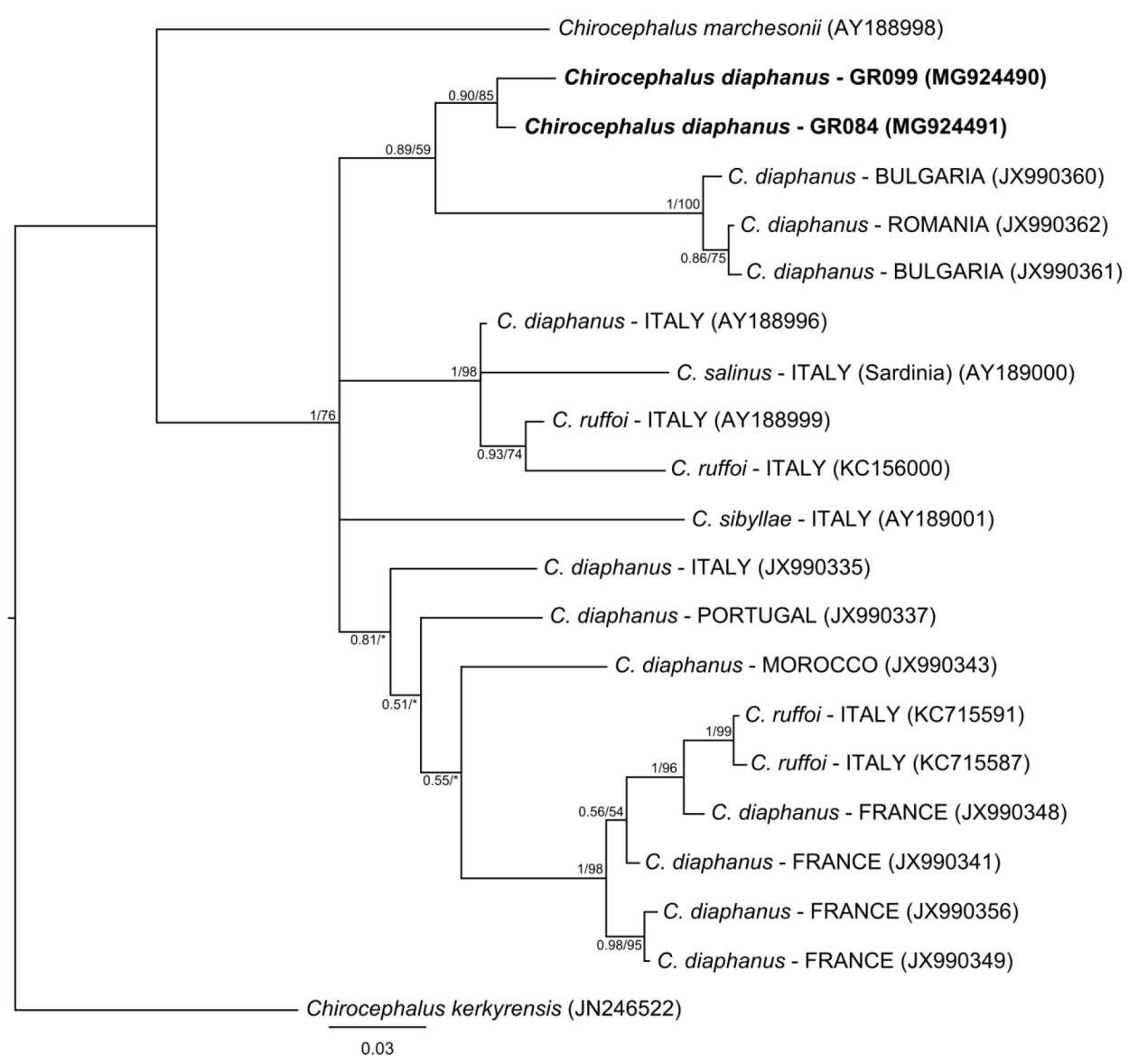

Figure 2. Bayesian consensus phylogram based on a 408-bp-long fragment of the mitochondrial gene encoding for the cytochrome oxidase subunit I (mtDNA COI). Node support is reported as nodal posterior probability/ML bootstrap; nodal posterior probability lower than 0.5 is represented as an unresolved polytomy; “*” indicates bootstrap support lower than 50 . Accession numbers of sequences derived from GenBank are shown in brackets. Cretan samples are reported in bold. Árbol filogenético de consenso Bayesiano basado en el fragmento largo 408-bp del gene mitocondrial codificado por la subunidad I citocromo oxidasa (mtDNA COI). El soporte de los nodos se muestra como la probabilidad posterior nodal /ML bootstrap; la probabilidad posterior nodal inferior a 0.5 se representa como una politomía no resuelta. "*” indica un soporte boostrap inferior a 50. Entre paréntesis los números de acceso de las secuencias derivadas del GenBank. En negrita las muestras de Creta.

sequences belonging to other $C$. diaphanus s.1. populations and other Chirocephalus species were downloaded from GenBank and included in the analyses (Fig. 2).

Calanoid copepods were prepared according to Dussart and Defaye (2001), and line drawings of specimens of the genus Arctodiaptomus were made using a compound microscope equipped with a camera lucida. Drawings were based on specimens collected in GR084, an ancient temporary pond located on the Omalos plateau (Chania, Crete). Two specimens of Arctodiaptomus cf. piliger from sites GR088 and GR099 (Crete, Greece), one specimens of $A$. alpinus from Greek mainland (Central Greece), one specimen of Arctodiaptomus cf. alpinus from Mongolia (Tov province), one specimen of Arctodiaptomus belgrati Mann, 1940 from Romania (Ciuc basin), and one specimen of Arctodiaptomus kerkyrensis Pesta, 1935 from Italy (Basilicata) were studied by amplifying and sequencing a fragment of the mitochondrial gene encoding for the cytochrome b (Cyt-b). Cyt-b sequences proved to be informative about the molecular systematics of the genus 


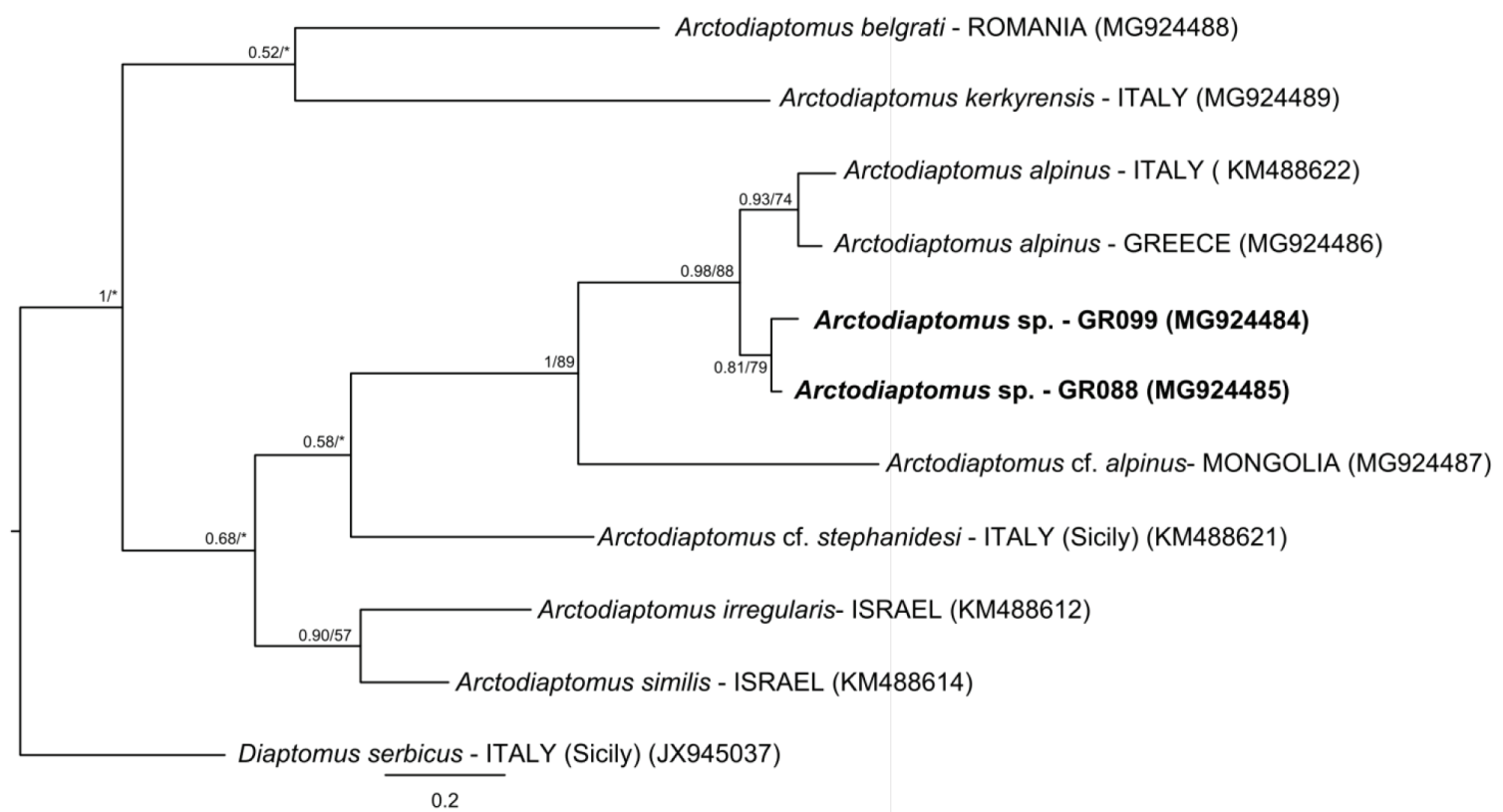

Figure 3. Bayesian consensus phylogram based on a 313-bp-long fragment of the mitochondrial gene encoding for the cytochrome $b$ (mtDNA Cyt-b). Node support is reported as nodal posterior probability/ML bootstrap; nodal posterior probability lower than 0.5 is represented as an unresolved polytomy, "*” indicates bootstrap support lower than 50. Accession numbers of sequences derived from GenBank are shown in brackets. Cretan samples are reported in bold. Árbol filogenético de consenso Bayesiano basado en el fragmento largo 313-bp del gene mitocondrial codificado por la subunidad I citocromo oxidasa (mtDNA Cyt-b). El soporte de los nodos se muestra como la probabilidad posterior nodal /ML bootstrap; la probabilidad posterior nodal inferior a 0.5 se representa como una politomía no resuelta. “*” indica un soporte boostrap inferior a 50. Entre paréntesis los números de acceso de las secuencias derivadas del GenBank. En negrita las muestras de Creta.

Arctodiaptomus (Marrone et al., 2014); accordingly, this molecular marker was chosen with the aim of comparing the allegedly endemic Cretan species Arctodiaptomus piliger Brehm, 1955 and different populations of the closely related $A$. alpinus (Imhof, 1885). Moreover, comparative sequences belonging to an $A$. alpinus population from the Italian Alps and other species of the genera Arctodiaptomus and Diaptomus were downloaded from GenBank and used in the analyses (Fig. 3).

DNA extraction and amplification were performed following the protocols and procedures described in Marrone et al. $(2010,2013)$ for copepods, and Cottarelli et al. (2017) for anostracans. Chromatograms were visualised and edited using Chromas Lite 2.01 (Technelysium Pty Ltd., South Brisbane, Australia), and aligned in ClustalX (Thompson et al., 1997). MEGA7 (Kumar et $a l ., 2016)$ was used to translate the Cyt-b and COI sequences to amino acids in order to check for the possible presence of frameshifts or stop codons, which would indicate the presence of sequencing errors or pseudogenes. The sequences were deposited in GenBank under Accession Numbers MG924484-MG924489 (Arctodiaptomus spp.) and MG924490-MG924491 (Chirocephalus diaphanus s.1.).

Bayesian inference (BI) of phylogeny and maximum likelihood (ML) analyses were performed on the Cyt-b dataset as implemented by MrBayes 3.2 (Ronquist et al., 2012) and PhyMl v.3 (Guindon \& Gascuel, 2003), respectively. The choice of the best evolutionary model was made using MrModeltest 2.2 (Nylander 2004) on the basis of Akaike Information Criterion (AIC) for both analyses and datasets; accordingly, a Hasegawa-Kishino-Yano nucleotide substitution model with gamma distributed rate variation among sites $(\mathrm{HKY}+\mathrm{G}$; nst $=2)$ was used 
for the "Chirocephalus dataset", and a General Time Reversible model with gamma distributed rate variation among sites and a proportion of invariant sites $(\mathrm{GTR}+\mathrm{I}+\mathrm{G}$; nst $=6)$ was used for the "Arctodiaptomus dataset". Node supports were evaluated by their posterior probabilities in the BI and by 1000 bootstrap replicates in the ML analyses. The BI analyses were performed with two independent runs of 1 x 106 generations and four Markov chains using default heating values. Trees and parameter values were sampled every 100 generations resulting in $10 \times 10^{3}$ saved trees per analysis. An initial fraction of 2000 trees (20 \%) was conservatively discarded as burn-in. For all analyses and both datasets, standard deviation of split frequencies reached values lower than 0.018288 , and values of the potential scale reduction factor (PSRF) were comprised between 0.999 and 1.002 for all the partitions with frequency $\geq 0.10$ in at least one run, indicating convergence of the runs.

\section{RESULTS}

Four permanent and 17 temporary water bodies spread throughout Crete, from sea level up to 1330 $\mathrm{m}$ a.s.1., were sampled (Fig. 1 and Table 1; Table S2 and Fig. S1 available at http://www.limnetica. net/en/limnetica). Zooplankton samples were available from 8 sites only; sediment samples were collected in further 10 sites, since these were dry when sampling was performed. The crustacean fauna occurring in 3 additional sites was studied based both on direct crustacean samplings and sediment culturing (Table 1; Table S1 available at http://www.limnetica.net/en/limnetica).

Overall, 46 non-malacostracan crustacean taxa (17 Branchiopoda, 10 Copepoda, and 19 Ostracoda) were collected in the present study, and 27 of these are new for the Cretan fauna. These results therefore bring to 78 the number of non-malacostracans species up to now known for the island (Table 2). Most of the collected taxa were identified at species level, although this proved not to be possible for the cladocerans Ilyocryptus sp. from GR083 and GR094 and Leydigia sp. from GR084, and the ostracods Cypridopsis sp. (from GR152), Candona sp. (from GR094), Ilyocypris sp. (from GR089,
GR094, GR099), and Eucypris sp. occurring in GR092 and GR151.

A single anostracan species morphologically ascribed to Chirocephalus diaphanus Prévost, 1803 was found in five of the studied sites (Table 2; Fig. S2 available at http://www.limnetica.net/ en/limnetica). Upon aligning our Cretan Chirocephalus sequences and those downloaded from GenBank, and having trimmed the tails of the sequences which were not present in all the individuals, we obtained a properly aligned 408 bp-long fragment of the mtDNA COI. BI and ML trees, rooted on Chirocephalus kerkyrensis Pesta, 1936 (a species belonging to the bairdi-species group of the genus Chirocephalus, see discussion in Cottarelli et al., 2017), showed a consistent topology at the major nodes (Fig. 2). The sequences of the Cretan Chirocephalus specimens form the sister clade of $C$. diaphanus s.1. sequences from Bulgaria and Romania, i.e. were included in the "eastern clade" of $C$. diaphanus s.1., which should be ascribed to the binomen Chirocephalus romanicus Stoicescu, 1992 according to Reniers et al. (2013).

The widespread Ceriodaphnia sp., observed in 6 out of the 21 studied sites, corresponds to the taxon ascribed to Ceriodaphnia quadrangula Müller, 1785 by Alonso (1996). However, this is, in fact, a different widespread west-Palearctic species pending a formal description (M. Alonso, unpublished data).

Three species of calanoid copepods were collected in the frame of this survey: Calanipeda aquaedulcis Kritschagin, 1873, Neolovenula alluaudi (Guerne \& Richard, 1890), and a diaptomid belonging to the genus Arctodiaptomus. The morphology of both males and females of the latter species are presented in figures 4 and 5 , respectively.

Five cyclopoid and two harpacticoid species were collected during this survey (Table 2). Among these, the cyclopoids Acanthocyclops einslei Mirabdullayev \& Defaye, 2004, the widespread Metacyclops minutus (Claus, 1863), and the brackish water harpacticoid Cletocamptus retrogressus Schmankevitsch, 1875 are new records from Crete. 
Table 2. Checklist of the non-stygobitic taxa cited for Crete island; codes of the sites of occurrences according to table 1. References: 1: Kiefer (1928); 2: Chappuis (1929); 3: Klie (1941); 4: Brehm (1955); 5: Lindberg (1956); 6: Chappuis (1956); 7: Pesce \& Maggi (1981); 8: Petkowski et al. (2000); 9: Karaouzas et al. (2000); 10: Present work.; 1: “C. quadrangula” sensu Alonso (1996) and probably sensu Brehm (1955); 2: described as A. piliger by Brehm (1955); ${ }^{3}$ : uncertain identification; cited as Cyclops strenuus (Chappuis, 1929) and Cyclops rubens rubens (Lindberg, 1956); 4 : reported as Cyclops bicuspidatus odessanus (Chappuis, 1929) and Acanthocyclops bicuspidatus f. odessana (Lindberg, 1956). Relación de los taxones no estigobíticos citados en la isla de Creta; códigos de las localidades donde aparecen de acuerdo con la tabla 1. Referencias: 1: Kiefer (1928); 2: Chappuis (1929); 3: Klie (1941); 4: Brehm (1955); 5: Lindberg (1956); 6: Chappuis (1956); 7: Pesce \& Maggi (1981); 8: Petkowski et al. (2000); 9: Karaouzas et al. (2000); 10: Present work.; 1. "C. quadrangula" sensu Alonso (1996) y probablemente sensu Brehm (1955); 2 : descrito como A. piliger por Brehm (1955); 3: identificación dudosa; citado como Cyclops strenuus (Chappuis, 1929) y Cyclops rubens rubens (Lindberg, 1956); 4 : reportado como Cyclops bicuspidatus odessanus (Chappuis, 1929) y Acanthocyclops bicuspidatus $f$. odessana (Lindberg, 1956).

\begin{tabular}{|c|c|c|}
\hline Taxa & References & $\begin{array}{l}\text { Sites of occurrence } \\
\text { (Present work) }\end{array}$ \\
\hline \multicolumn{3}{|l|}{ BRANCHIOPODA } \\
\hline \multicolumn{3}{|l|}{ Anostraca } \\
\hline \multicolumn{3}{|l|}{ Chirocephalidae } \\
\hline Chirocephalus diaphanus s.I. Prévost, 1803 & 9,10 & GR084, GR088, GR094, GR099, GR175 \\
\hline \multicolumn{3}{|l|}{ Anomopoda } \\
\hline \multicolumn{3}{|l|}{ Daphniidae } \\
\hline Daphnia (Ctenodaphnia) atkinsoni Baird, 1859 & 10 & GR151 \\
\hline Daphnia (Ctenodaphnia) chevreuxi Richard, 1896 & 10 & GR088, GR094, GR099 \\
\hline Simocephalus vetulus (Müller, 1776) & 4,10 & GR084, GR087, GR100 \\
\hline Ceriodaphnia sp. ${ }^{1}$ & 4,10 & GR084, GR087, GR088, GR094, GR099, GR152 \\
\hline Ceriodaphnia reticulata (Jurine, 1820) & 4,10 & GR085 \\
\hline \multicolumn{3}{|l|}{ Moinidae } \\
\hline Moina brachiata (Jurine, 1820) & 10 & GR099 \\
\hline Moina micrura Kurz, 1875 & 10 & GR084, GR088 \\
\hline \multicolumn{3}{|l|}{ Ilyocryptidae } \\
\hline Ilyocryptus sp. & 10 & GR083, GR094 \\
\hline \multicolumn{3}{|l|}{ Macrothricidae } \\
\hline Macrothrix hirsuticornis Norman \& Brady, 1867 & 10 & GR084, GR088, GR094, GR099, GR100, GR151 \\
\hline \multicolumn{3}{|l|}{ Chydoridae } \\
\hline Chydorus sphaericus (Müller, 1776) & $4,5,10$ & GR084, GR100 \\
\hline $\begin{array}{l}\text { Ovalona anastasia (Sinev, Alonso, Miracle \& Sahuquillo, } \\
\text { 2012) }\end{array}$ & 10 & GR084 \\
\hline Ovalona nuragica (Margaritora, 1971) & 10 & GR084 \\
\hline Alona affinis (Leydig, 1860) & 4,5 & --- \\
\hline Alona salina Alonso, 1996 & 10 & GR091, GR096 \\
\hline Alonella excisa (Fischer, 1854) & 4,5 & --- \\
\hline Alonella exigua (Lilljeborg, 1853) & 5 & --- \\
\hline Alonella nana (Baird, 1843) & 5 & --- \\
\hline Coronatella rectangula (G.O. Sars, 1862) & 10 & GR085, GR087, GR097, GR099, GR100 \\
\hline Leydigia iberica Kotov \& Alonso, 2010 & 10 & GR088 \\
\hline Leydigia sp. & 10 & GR084 \\
\hline \multicolumn{3}{|l|}{ COPEPODA } \\
\hline \multicolumn{3}{|l|}{ Calanoida } \\
\hline \multicolumn{3}{|l|}{ Pseudodiaptomidae } \\
\hline Calanipeda aquaedulcis Kritschagin, 1873 & 4,10 & GR082 \\
\hline \multicolumn{3}{|l|}{ Diaptomidae } \\
\hline Arctodiaptomus (Rhabdodiaptomus) alpinus (Imhof, 1855)² & 4,10 & GR084, GR088, GR099, GR100, GR152 \\
\hline Neolovenula alluaudi (Guerne \& Richard, 1890) & 7,10 & GR084, GR085 \\
\hline \multicolumn{3}{|l|}{ Cyclopoida } \\
\hline \multicolumn{3}{|l|}{ Cyclopidae } \\
\hline Macrocyclops albidus (Jurine, 1820) & 5 & --- \\
\hline Eucyclops serrulatus (Fischer, 1851) & $2,5,7$ & --- \\
\hline Ectocyclops phaleratus (Koch, 1838) & 5 & --- \\
\hline Tropocyclops prasinus (Fischer, 1860) & $2,5,10$ & GR085, GR087 \\
\hline Paracyclops fimbriatus (Fischer, 1853) & 5,7 & --- \\
\hline
\end{tabular}


Table 2. (cont.)

\begin{tabular}{|c|c|c|}
\hline Cyclops sp. ${ }^{3}$ & 2,5 & --- \\
\hline Megacyclops viridis (Jurine, 1820) & $5,7,10$ & GR085 \\
\hline Acanthocyclops einslei Mirabdullayev \& Defaye, 2004 & 10 & GR083 \\
\hline Diacyclops bisetosus (Rehberg, 1880) & 7 & --- \\
\hline Diacyclops lubbocki (Brady, 1869) ${ }^{4}$ & $2,5,7,10$ & GR086, GR091 \\
\hline Diacyclops crassicaudis (G.O. Sars, 1863) & $1,2,7$ & --- \\
\hline Thermocyclops oblongatus (G.O. Sars, 1927) & 5,7 & -- \\
\hline Metacyclops minutus (Claus, 1863) & 10 & GR098, GR151 \\
\hline \multicolumn{3}{|l|}{ Harpacticoida } \\
\hline \multicolumn{3}{|l|}{ Canthocamptidae } \\
\hline Mesochra aestuarii Gurney, 1921 & 6 & --- \\
\hline Canthocamptus staphylinus (Jurine, 1820) & $2,6,10$ & GR084 \\
\hline Attheyella (Attheyella) crassa (Sars, 1863) & 2 & --- \\
\hline Bryocamptus (Bryocamptus) minutus (Claus, 1863) & 2,6 & --- \\
\hline Bryocamptus (Rheocamptus) pygmaeus (Sars, 1863) & 2,6 & --- \\
\hline Bryocamptus (Rheocamptus) zschokkei (Schmeil, 1893) & 2 & --- \\
\hline Elaphoidella denticulata Chappuis, 1929 & 2 & --- \\
\hline Maraenobiotus vejdovskyi Mrazek, 1893 & 6 & --- \\
\hline Maraenobotus brucei carpathicus Chappuis, 1928 & 6 & --- \\
\hline Cletocamptus retrogressus Schmankevitsch, 1875 & 10 & GR086, GR091, GR097 \\
\hline \multicolumn{3}{|l|}{ Ameiridae } \\
\hline Nitokra lacustris (Shmankevich, 1875) & 6 & --- \\
\hline \multicolumn{3}{|l|}{ Laophontidae } \\
\hline Onychocamptus mohammed (Blanchard \& Richard, 1891) & 6 & --- \\
\hline \multicolumn{3}{|l|}{ OSTRACODA } \\
\hline \multicolumn{3}{|l|}{ Podocopida } \\
\hline \multicolumn{3}{|l|}{ Candonidae } \\
\hline Candona lindneri Petkovski, 1969 & 10 & GR088 \\
\hline Candona neglecta Sars, 1887 & 3 & --- \\
\hline Candona sp. & 10 & GR094 \\
\hline Pseudocandona pratensis (Hartwig, 1901) & 3 & --- \\
\hline Candonopsis kingsleii (Brady \& Robertson, 1870) & 3 & --- \\
\hline \multicolumn{3}{|l|}{ Ilyocypridae } \\
\hline Ilyocypris sp. & 10 & GR088, GR094, GR099 \\
\hline Ilyocypris bradyi Sars, 1890 & 3 & --- \\
\hline Ilyocypris divisa Klie, 1926 & 3 & --- \\
\hline Ilyocypris gibba (Ramdohr, 1808) & 3,10 & GR091 \\
\hline Ilyocypris getica Masi, 1906 & 10 & GR100 \\
\hline \multicolumn{3}{|l|}{ Cyprididae } \\
\hline Cypris bispinosa Lucas, 1849 & 10 & GR083, GR087 \\
\hline Eucypris kerkyrensis Stephanides 1937 & 8 & --- \\
\hline Eucypris virens (Jurine, 1820) & 3,10 & GR091, GR099, GR100 \\
\hline Eucypris sp. & 10 & GR092, GR151 \\
\hline Tonnacypris lutaria (Koch, 1838) & 8,10 & GR098, GR100, GR151 \\
\hline Herpetocypris chevreuxi (Sars, 1896) & $3,8,10$ & GR084 \\
\hline Herpetocypris reptans Cole, 1965 & 3 & --- \\
\hline Stenocypria fischeri (Lilljeborg, 1883) & 10 & GR100 \\
\hline Heterocypris barbara (Gauthier \& Brehm, 1928) & 10 & GR086, GR094, GR097, GR099, GR100, GR151 \\
\hline Heterocypris incongruens (Ramdohr, 1808) & $3,8,10$ & GR086, GR091, GR096, GR098, GR100, GR151 \\
\hline Heterocypris salina (Brady, 1868) & 3,8 & --- \\
\hline Cypria ophtalmica (Jurine, 1820) & 3 & --- \\
\hline Cypridopsis vidua (O.F. Müller, 1776) & 10 & GR083 \\
\hline Cypridopsis hartwigi G.W. Müller, 1900 & 10 & GR100 \\
\hline Cypridopsis elongata (Kaufmann, 1900) & 10 & GR100 \\
\hline Plesiocypridopsis newtoni (Brady \& Robertson, 1870) & 3 & --- \\
\hline Sarscypridopsis aculeata (Costa, 1847) & 10 & GR085, GR091, GR097, GR152 \\
\hline Potamocypris arcuata (Sars, 1903) & 10 & GR088, GR094, GR098, GR099, GR100 \\
\hline \multicolumn{3}{|l|}{ Lymnocytheridae } \\
\hline Paralimnocythere psammophila (Flössner, 1965) & 10 & GR100 \\
\hline
\end{tabular}




\section{Morphological description of the Arctodiapto- mus specimens from Crete}

Male: Body length $1.410 \mathrm{~mm}$, shorter than in female (Fig. 4a). Urosome asymmetrical (Fig. 4b) with a strong spine on the right side of the first genital somite and scattered small setae (in variable number) on the other somites. Geniculate right antennula (Fig. 4e) with spines at the segment 8 and 10-13; length proportions as follows: $13>11>10>8>12$. Antepenultimate segment of right antennula with a spinous process shorter than the penultimate segment and with a rounded-hyaline terminal end (Fig. 4f), variable in different specimens (Fig. 4g). Rostral spines as in Fig. 4h. Posterior surface of the second endopodite segment of leg 2 with a weakly sharpened "Schmeil's organ" (Fig. 4d). Right fifth leg (P5, Fig. 4c) with chitinous processes on the inner side of basis and on the second exopodite segment; distal claw with a proximal 'curve' as in A. steindachneri (Richard, 1897); lateral spine as long as one half of distal claw.

Female: Size $1.615 \mathrm{~mm}$. Habitus as in Fig. 5a. Urosome slightly asymmetrical (Figs. 5b, 5c) with spines on both sides of the genital somite in variable position, but with the left spine always pointed down with respect to the right one. Antennula (Fig. 51) with a long seta on the first segment ("dentifer") reaching the 8th segment. Two setae on segments 11 and 13, one seta on segments 15 and 17. P5 (Fig. 5d) with robust coxal spines and small sensilla variable both in number and position (Figs. 5e, 5g). Endopodite of fifth pair of legs indistinctly 2 -segmented with setulae on the inner side (Figs. 5f, 5h, 5i); a setula can be present only on a single segment or in both the indistinct segments; variability was observed even in the same specimen in left and right legs (Figs. 5h, 5i).

By analysing the morphological features of the collected specimens, it was noticed that the morphological characters (and the drawings) originally used by Brehm (1955) to describe the species Arctodiaptomus piliger do not allow to distinguish it from the congeneric A. alpinus (Imhof, 1885). These results were confirmed by the molecular analyses based on a $313 \mathrm{bp}-$ long fragment of the Cyt-b gene. In both the BI and
ML trees (Fig. 3), which showed a concordant topology at the major nodes, Cretan Arctodiaptomus cf. piliger sequences clustered with Arctodiaptomus alpinus s.s. sequences from Italy and Greece. Conversely, Arctodiaptomus cf. alpinus reported for Mongolia by Marrone et al. (2015) forms the sister group of the studied European $A$. alpinus populations. The $26 \%$ of uncorrected p-distance between the Mongolian sample and the European A. alpinus s.s. populations is even higher than that observed between the sister species A. similis (Baird, 1859) and A. irregularis Dimentman \& Por, 1985 (Marrone et al., 2014), thus suggesting that the Mongolian taxon might actually represent a cryptic species related to $A$. alpinus s.s.

\section{DISCUSSION}

To date, the microcrustaceans and large branchiopods of the inland waters of Crete were poorly known. While several papers dealing with the stygobitic copepods of Crete were published in the XX century (e.g. Chappuis, 1929, 1956; Lindberg, 1956; Pesce \& Maggi, 1981, 1983 and references therein), the Cretan surface non-malacostracan crustaceans, to our knowledge, were the object of a few studies only (Chappuis, 1929; Klie, 1941; Brehm, 1955; Lindberg, 1956; Karaouzas et al., 2015). Although the present work admittedly does not provide an exhaustive list of Cretan inland water non-malacostracan crustaceans, it paves the way to further studies, and allows to carry out a first characterization of Cretan fauna. The vast majority of observed taxa are first records for Crete and/or for the eastern Mediterranean basin, further stressing the need of better exploring these areas.

A single anostracan species was observed; this result, although unexpected when the anostracan fauna of other large Mediterranean islands is considered (Brtek \& Thiéry, 1995), is in line with the paucity of large branchiopod records to date available for Greece (Abatzopoulos et al., 1999). Its morphology is compatible with those described for the subspecific taxa $C$. diaphanus carinatus Daday, 1910 (locus typicus: valley of river Vardar\Axios, Greece), $C$. diaphanus pentheri Pesta, 1921 (locus typicus: Kukës, Alba- 

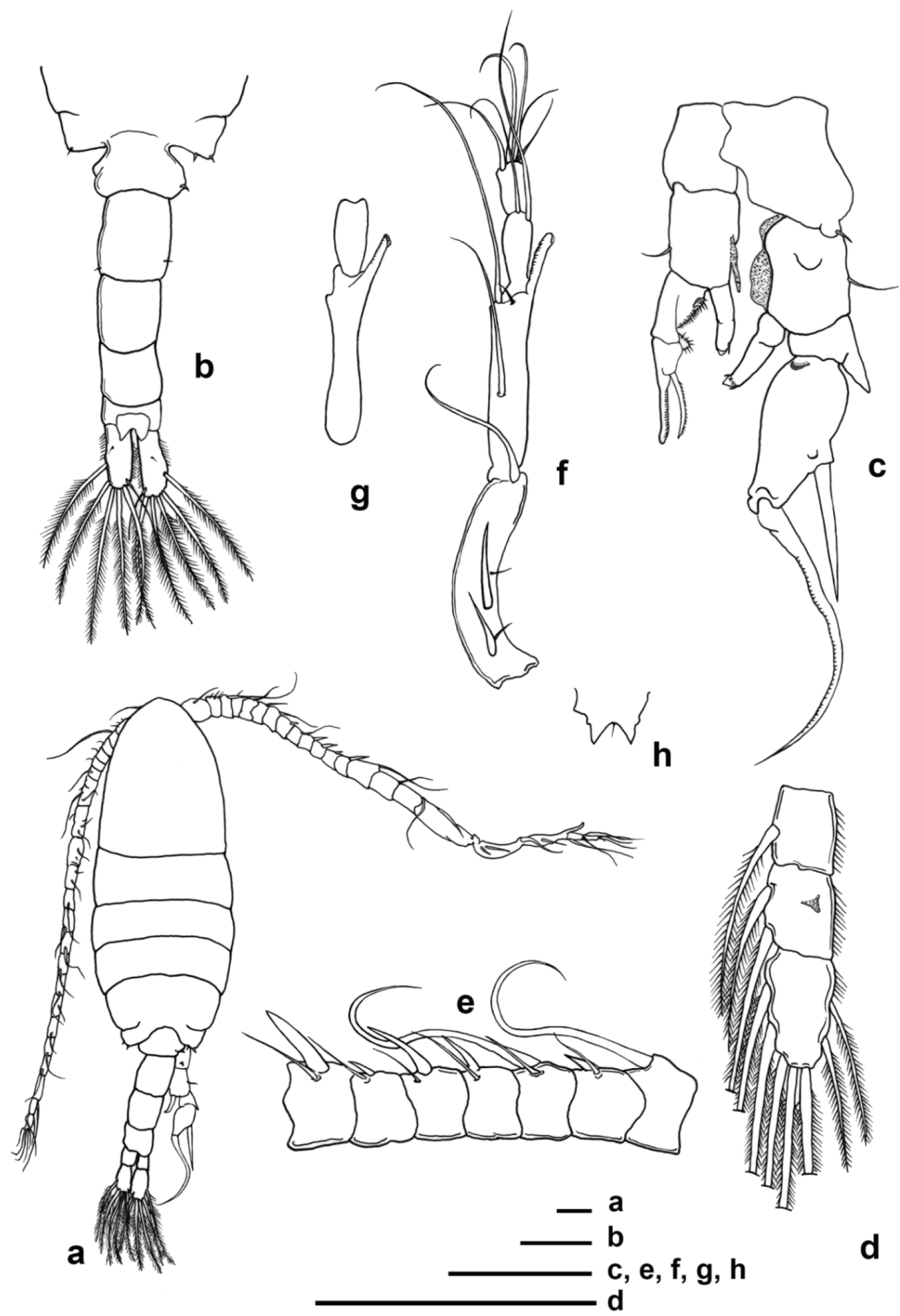

Figure 4. Arctodiaptomus alpinus from Crete (GR084); Male. a: habitus; b: urosome; c: fifth pair of legs; d: second leg; e: right antennula (segments 7-13); f: antepenultimate segment of the right antennula; g: as in $\mathrm{f}$ (different specimen). Scale bar: $0.1 \mathrm{~mm}$. Drawings by GA. Arctodiaptomus alpinus de Creta (GR084); Macho. a: habitus; b: urosoma; c: quinto par de patas; d: segunda pata; e: anténula derecha (segmentos 7-13); $f$ : antepenúltimo segmento de la anténula derecha; $g$ : como en $f$ (ejemplar diferente). Barra de escala: $0.1 \mathrm{~mm}$. Ilustraciones de GA. 


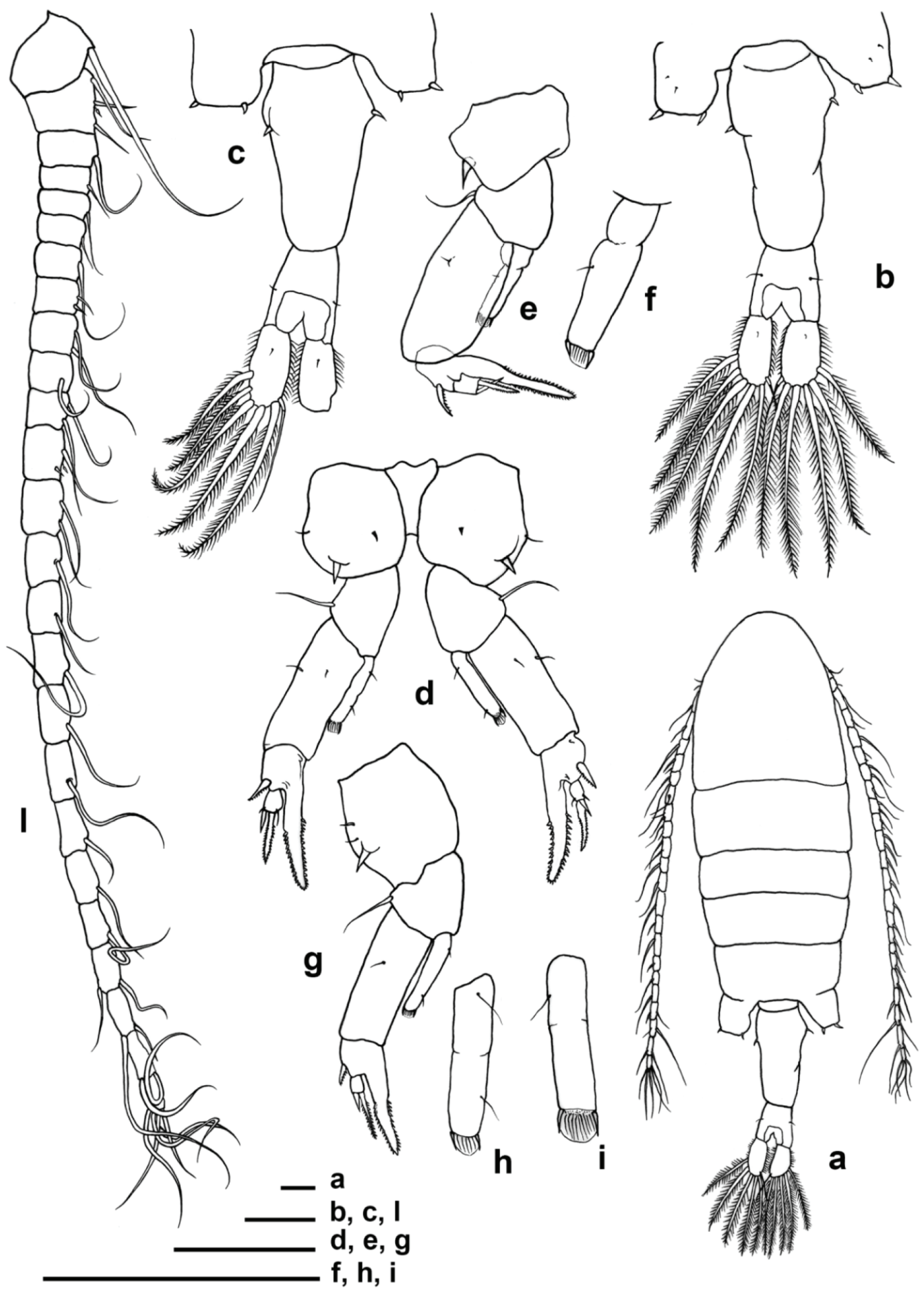

Figure 5. Arctodiaptomus alpinus from Crete (GR084); Female. a: habitus; b, c: urosome; e, d, g: fifth pair of legs; f, h, i: endopodite of fifth leg; 1: A1. (Specimen 1: a, b, d, 1; Specimen 2: c, g, h, I; Specimen 3: e, f). Scale bar: 0.1 mm. Drawings by GA. Arctodiaptomus alpinus de Creta (GR084); Hembra. a: habitus; $b$, c: urosoma; e, $d$, g: quinto par de patas; $f$, $h$, $i$ : endopodito de la quinta pata; $l:$ Al. (Ejemplare 1: $a, b, d, l$; Ejemplare 2: c, g, h, I; Ejemplare 3: e, f). Barra de escala: $0.1 \mathrm{~mm}$. Ilustraciones de GA. 
nia) and C. diaphanus romanicus Stoicescu, 1962 (locus typicus: Olteniţa, Romania), although, as stressed by several authors (e.g. Belk \& Brtek, 1995; Marincek \& Petrov, 1995; Mura et al., 2002; Reniers et al., 2013) a proper distinction of $C$. diaphanus subspecies is not always straightforward, and a revision of this species-group is needed. The molecular analyses of the Cretan Chirocephalus from GR084 and GR099 clustered the two analysed specimens within the "eastern clade" of C. diaphanus, which included samples from Romania and Bulgaria. According to Reniers et al. (2013) this clade should be worth of species status under the binomen Chirocephalus romanicus. However, in the light of the wide morphological plasticity of $C$. diaphanus s.l. and of the morphological similarity among its eastern subspecies, "C. romanicus" might in fact prove to be just a junior synonym of $C$. pentheri or $C$. carinatus. Accordingly, pending a revision of the systematics and taxonomy of the diaphanus-group of the genus Chirocephalus, which includes samples from the type localities of all the described taxa, we prefer to report the Cretan Chirocephalus as $C$. diaphanus s.l., refraining from assigning it to any other taxon of specific or subspecific rank. In Greece, C. diaphanus s.l. was already reported for Zante (Stephanides, 1948), Boeotia (Pesta, 1921) and Macedonia (Daday, 1910). Moreover, Karaouzas et al. (2015) report the presence of Chirocephalus sp. from Omalos temporary pond (Crete), i.e the site coded as GR084 in the present study.

In the last decades, careful morphological studies confirmed that, as anticipated by Frey (1982), the paradigm of cosmopolitanism of freshwater taxa was inapplicable to anomopods, and that their actual diversity was largely underestimated (Forró et al., 2008). Accordingly, several new species were recently described, even in well-studied regions, especially among the radopods. These taxa, originally considered endemic to their terra typica, are now being observed even in relatively-distant regions, thus better defining their distribution. This is the case for some alleged west-Mediterranean endemic taxa as Ovalona anastasia (Sinev, Alonso, Miracle \& Sahuquillo, 2012), Ovalona nuragica (Margaritora, 1971), Alona salina Alonso, 1996 and Leydigia iberica
Kotov \& Alonso, 2010, whose presence on an island of the eastern Mediterranean Sea was rather unexpected and further stresses the need for a careful re-examination of the anomopod fauna of the eastern Mediterranean countries.

The observed Cretan copepod fauna is rather poor when compared to other large Mediterranean islands (e.g. Sicily, Corsica, or Sardinia). These are usually inhabited by 6-11 diaptomid species, and even the relatively-small Balearic Islands and Corfu respectively host five and six diaptomid species (Marrone et al., 2009). These numbers are significantly higher than the two diaptomid species observed on Crete. This paucity is likely to be ascribed to the inadequacy of sampling and/or of the used culturing techniques for the hatching or raising of calanoid copepods. Actually, Crete has a climate, geographic location and physiography which should allow the presence of a much richer diaptomid fauna (Marrone et al., 2017). The same applies to cyclopoid and harpacticoid copepods, whose observed species richness is almost completely due to the few samples collected during the wet phase of the water bodies, while only three species, i.e. Diacyclops lubbocki (Brady, 1869), Metacyclops minutus (Claus, 1863) and Cletocamptus retrogressus Schmankevitsch, 1875 hatched in the cultures (see Table S1, available at http://www.limnetica. net/en/limnetica). It is then obvious that different culturing methods are to be developed and implemented to efficiently use the Sars' method for censing the copepods occurring in a given area. Until culturing methodologies are optimised, the study of copepods should be primarily based on collections in the field. It is likely that an increased sampling effort will lead to the finding of several other copepod taxa, including representatives of the diaptomid genera Mixodiaptomus and Hemidiaptomus which are among the most typical copepod inhabitants of Mediterranean temporary ponds (Miracle, 1982; Sahuquillo \& Miracle, 2013).

The three calanoid copepods recorded in the frame of this survey were already known to occur on the island (Brehm, 1955; Pesce \& Maggi, 1981; Alfonso \& Belmonte, 2013). Interestingly, we found abundant populations of the alleged Cretan endemic diaptomid Arctodiaptomus 
piliger in five temporary ponds spread throughout the island. The species was only sketchy described by Brehm (1955) and never collected again since its original description so that providing more details on its morphology and ecology was considered pivotal according to Kiefer (1978), Ranga-Reddy (1994) and Błędzki \& Rybak (2016). Arctodiaptomus piliger was ascribed to the bacillifer-group sensu Kiefer (1971) based on the occurrence of two setae on the 13th antennulary segment. According to the original description, the only morphological character which would be discriminative of $A$. piliger and which would have differentiated this taxon from the closely-related $A$. alpinus was the presence of "long hairs" on the endopodites of female fifth pair of legs. This character, however, has no taxonomic value since it is routinely reported for most Arctodiaptomus species, including Arctodiaptomus alpinus (cf. Dussart, 1967; Petkovski, 1983; Stella, 1984; Kiefer, 1971, 1978; and personal observations). Moreover, the molecular identification of Cretan Arctodiaptomus specimens from two sites located more than $210 \mathrm{~km}$ apart on the island, consistently showed their conspecificity with Arctodiaptomus alpinus populations from the Italian Alps and from Central Greece. Morphological re-examination and molecular analyses of alleged Arctodiaptomus piliger are thus concordant in supporting the synonymization of this species with the widespread Arctodiaptomus alpinus, a species also occurring on mainland Greece (present data) and spread throughout the Palearctic (Dussart \& Defaye, 2002; Flössner et al., 2005; but see also: Marrone et al., 2015), which is here formally indicated as the senior synonym of $A$. piliger. The possible occurrence of Arctodiaptomus alpinus on Crete suggested by Kiefer (1971, pag. 148) and reported (but not discussed) by Ranga-Reddy (1994), Jersabek et al. (2011, Fig.7) and Błędzki \& Rybak (2016, figure at pag. 491) is thus here fully confirmed. Our findings provide some unprecedented information on the ecology of the species, which was usually considered a "cold stenothermal species, occurring preponderantly in the lakes of high places in the Alps (altitude 2000-2700 m)" (Ranga-Reddy, 1994) and a "real high-altitude species with a strong preference for ultraoligotrophic alpine lakes above the timberline" (Błędzki \& Rybak, 2016). Conversely, in Crete the species was collected in eutrophic temporary ponds and pools frequented by livestock, and located in the range 539-1330 m a.s.l. In some cases, it co-occurred with Neolovenula alluaudi, a Paradiaptominae copepod considered typical of steppic regions (Jaume, 1989-1990; Alfonso \& Belmonte, 2013).

All the cyclopoid and harpacticoid species collected so far from surface waters in Crete are widespread in the Mediterranean bioregion as well as across the Palearctic, confirming their high dispersal and colonization ability. Metacyclops minutus was found so far only in temporary ponds and pools, showing a preference for small and ephemeral water bodies (Dussart, 1969; Einsle, 1993); it was the species most commonly obtained by the "Hydration Experiments".

To our knowledge, Klie (1941) and Petkowski et al. (2000) were the only authors who provided data on the ostracod fauna of Crete, altogether listing 15 species; among these, 10 were not found in the present study. Accordingly, considering both the data of Klie (1941) and the present data, the ostracod fauna of Crete at present includes 29 taxa. Among ostracods, the findings of Ilyocypris sp., a taxon already recorded from Greece (Mazzini et al., 2014), peninsular Italy (Alfonso et al., 2016) and Tunisia (unpublished data), and Eucypris sp. are noteworthy. These taxa are currently under study and might be species new to Science pending a formal description. Moreover, the specific allocation of both Candona sp. and Cypridopsis sp. remained uncertain, due to either absence of males or presence of exclusively juvenile specimens.

Based on the currently available data, the non-malacostracan crustacean fauna of the inland waters of Crete is a typically Mediterranean one, including both steppic and more temperate taxa. However, the well-developed orography of the island also allows the presence of species, as the calanoid copepod Arctodiaptomus alpinus, which are typical of colder climates. These organisms might represent in Crete relic taxa which colonised the island during Pleistocene glaciations and found at higher altitudes microthermal refuges where to survive the Holocene climate warm- 
ing. Interestingly, in accordance to what observed in other large Mediterranean islands, no endemic taxa were found among the species inhabiting surface water bodies, while the microcrustacean stygofauna of Crete and other Mediterranean islands is well-diversified and characterised by the presence of strict endemics like the cyclopoid copepods of the genus Speocyclops (Lindberg, 1955, 1956; Pesce \& Maggi, 1983) or the harpacticoid copepods of the genus Elaphoidella (Chappuis, 1929, 1956). This pattern is likely to be ascribed to the high potential for passive dispersal shown by organisms producing resting stages, and to their consequent ability of both rapidly colonising newly suitable habitats and likely maintaining an effective gene-flow among populations (see Kappas et al., 2017), although some contrasting evidences on this topic are also available (Incagnone et al., 2015).

The occurrence in Crete of several anomopod species currently considered endemic of the western Mediterranean area highlights the importance of the so-called Wallacean shortfall (Whittaker et al., 2005) for certain "less charismatic" crustacean groups as the non-malacostracan crustaceans, and its bearing on our current understanding of their diversity patterns and biogeography.

\section{ACKNOWLEDGEMENTS}

D.E. Canale (Palermo, Italy), E. Dimitriou (Hellenic Centre for Marine Research, Greece), L. Fazan (University of Fribourg, Switzerland) and G. Ippolito (Artemisia Società Cooperativa, Italy) are kindly acknowledged for the support they provided in the frame of the sampling activities.

\section{REFERENCES}

ABATZOPOULOS, T.J., L. BRENDONCK \& P. SORGELOOS. 1999. First record of Branchinella spinosa (Milne-Edwards) (Crustacea: Branchiopoda: Anostraca) from Greece. International Journal of Salt Lake Research, 8: 351-360. DOI: 10.1007/BF02442120

ALFONSO, G., G. BELMONTE, P. ERNANDES \& V. ZUCCARELLO V. 2011. Stagni temporanei mediterranei in Puglia. Biodiversità e aspetti di un habitat poco cono- sciuto. Edizioni Grifo.

ALFONSO, G. \& G. BELMONTE. 2013. Neolovenula alluaudi (Guerne and Richard, 1890) (Calanoida: Diaptomidae: Paradiaptominae): first record in Italy and review of geographical distribution. Journal of Limnology, 72: 251-261. DOI: 10.4081/jlimnol. 2013.e20

ALFONSO, G., L. BECCARISI, V. PIERI, A. FRASSANITO \& G. BELMONTE. 2016. Using crustaceans to identify different pond types. A case study from the Alta Murgia National Park, Apulia (South-eastern Italy). Hydrobiologia, 782: 53-69. DOI: 10.1007/s10750-016-2669-y.

ALLEN, H. 2001. Mediterranean Ecogeography. Routledge, Oxford, UK.

ALONSO, M. 1996. Crustacea, Branchiopoda. In: (M.A. Ramos et al. eds.) Fauna Iberica, vol. 7. Museo Nacional de Ciencias Naturales. CSIC, Madrid.

ALVAREZ COBELAS, M., C. ROJO \& D.G. ANGELER. 2005. Mediterranean limnology: current status, gaps and the future. Journal of Limnology, 64: 13-29. DOI: 10.4081/jlimnol. 2005.13

BAGELLA, S., S. GASCÓN, R. FILIGHEDDU, A. COGONI, \& D. BOIX. 2016. Mediterranean Temporary Ponds: new challenges from a neglected habitat. Hydrobiologia, 782: 1-10. DOI: $10.1007 / \mathrm{s} 10750-016-2962-9$

BELK, D. \& J. BRTEK. 1995. Checklist of the Anostraca. Hydrobiologia, 298: 315-353. DOI: 10.1007/BF00033826

BŁĘDZKI, L.A. \& J.I. RYBAK. 2016. Freshwater crustacean zooplankton of Europe. Springer Nature, Switzerland. DOI: 10.1007/978-3-319-29871-9

BLONDEL, J., J. ARONSON, J.-Y. BODIOU \& G. BOEUF. 2010. The Mediterranean Region. Biological Diversity in Space and Time. 2nd Edition. Oxford University Press, Oxford, UK. BOIX, D., M.C. CARIA, S. GASCÓN, M.A. MARIANI, J. SALA, A. RUHÍ, J. COMPTE \& S. BAGELLA. 2017. Contrasting intra-annual patterns of six biotic groups with different dispersal mode and ability in Mediterranean temporary ponds. Marine and Freshwater Research, 68: 1044-1060. DOI: 10.1071/MF15435 
BORUTZKY, E.B., L.A. STEPANOVA \& M.S. KOSS. 1991. Opredelitel' Calanoida presnykh vod SSSR. Nauka, St. Petersburg.

BREHM, V. 1955. Calanoide Kopepoden und Cladoceren aus Kreta. Fragmenta Balcanica, 17(1): 149-155.

BRTEK, J. 1995. Some notes on the taxonomy of the family Chirocephalidae (Crustacea, Branchiopoda, Anostraca). Zbornik Slovenského národného múzea: Prírodné vedy, 41: 3-15.

BRTEK, J. \& A. THIÉRY. 1995. The geographic distribution of the European Branchiopods (Anostraca, Notostraca, Spinicaudata, Laevicaudata). Hydrobiologia, 298: 263-280. DOI: 10.1007/BF00033821

CHAMPEAU, A. \& A. THIÉRY. 1990. Les crustacés entomostracés des eaux stagnantes de Corse. Importance particulière des espèces monovoltines méditerranéennes de Copépodes Calanoïdes et d'Anostracés dans le sud-est de l'île. Bulletin de la Société Zoologique de France, 115: 55-75.

CHAPPUIS, P.A. 1929. Notes sur les Copépodes. 1. - Une nouvelle Attheyella du Japon. 2. Moraria Poppei Mrazek et Moraria brevipes Sars. 3. - Copépodes de Grèce. Bulletinul Societatii de Stiinte din Cluj, 4: 97-106.

CHAPPUIS, P.A. 1956. Harpacticoides récoltés en Crête par M.K. Lindberg. Folia Balcanica, 1: $15-18$.

COTTARELLI, V., G. MURA, G. IPPOLITO \& F. MARRONE. 2017. Chirocephalus sarpedonis sp. nov. (Branchiopoda, Anostraca, Chirocephalidae) from Turkey questions the monophyly of the traditional Chirocephalus species-groups. Hydrobiologia, 801: 5-20. DOI: $10.1007 / \mathrm{s} 10750-017-3271-7$

CULIOLI, J. L., C. MORI, A. ORSINI \& B. MARCHAND. 2006. Distribution and status of the large Branchiopoda (Crustacea) in Corsica, France. First International Symposium on Environment Identities and Mediterranean Area (ISEIMA). Corte-Ajaccio, Corsica, France, 9-12 July 2006: 271-273. DOI: 10.1109/ISEIMA.2006.344960

DADAY, E. 1910. Quelques phyllopodes anostracés nouveaux. Appendice a la monographie systématique des Phyllopodes Anostracés. Annales des sciences naturelles.
Zoologie, 12: 241-264.

DIAZ-PANIAGUA, C. 2015. El sistema de laguna temporales de Doñana, una red de hábitats acuáticos singualres. Organismo autónomo de parques nacionales, Ministerio de Agricultura, Alimentación y Medio Ambiente.

DIMITRIOU, E, I. KARAOUZAS, N. SKOULIKIDIS \& I. ZACHARIAS. 2006. Assessing the environmental status of Mediterranean temporary ponds of Greece. Annales de Limnologie - International Journal of Limnology, 42: 33-41. DOI: 10.1051/limn/2006004

DOWNING, J. 2010. Emerging global role of small lakes and ponds: little things mean a lot. Limnetica, 29: 9-24.

DOWNING, J., Y. T. PRAIRIE, J. J. COLE, C. M. DUARTE, L. J. TRANVIK, R. G. STRIEGL., W. H. MCDOWELL, P. KORTELAINEN, N. F. CARACO, J. M. MELACK \& J. J. MIDDELBURG. 2006. The global abundance and size distribution of lakes, ponds, and impoundments. Limnology and Oceanography, 51(5): 2388-2397. DOI: 10.4319/1o. 2006.51.5.2388

DUDGEON, D., A. H. ARTHINGTON, M. O. GESSNER, Z.-I. KAWABATA, D. J. KNOWLER, C. LÉVÊQUE, R. J. NAIMAN, A.-H. PRIEUR-RICHARD, D. SOTO, M. L. J. STIASSNY \& C. A. SULLIVAN. 2006. Freshwater biodiversity: importance, threats, status and conservation challenges. Biological Reviews, 81(2): 163-182. DOI: $10.1017 / \mathrm{S} 1464793105006950$.

DUSSART, B. 1967. Les copépodes des eaux continentales d'Europe Occidentale. I. Calanoïdes et Harpacticoïdes. Boubée et Cie, Paris.

DUSSART, B. 1969. Les copépodes des eaux continentales d'Europe Occidentale. II. Cyclopoïdes et biologie. Boubée et Cie, Paris.

DUSSART, B. \& D. DEFAYE. 2001. Introduction to the Copepoda, 2nd edition. Backhuys Publishers, Leiden

DUSSART, B. \& D. DEFAYE. 2002. World Directory of Crustacea Copepoda of Inland Waters, I. Calaniformes. Backhuys. Publisher, Leiden

EINSLE, U. 1993. Crustacea Copepoda. Calanoida und Cyclopoida. Süsswasserfauna Mitteleuropas, 8/4-1. Gustav Fisher Verlag. 
FLÖSSNER, D., W. HORN \& M. PAUL. 2005. Notes on the Cladoceran and Copepod fauna of the Uvs Nuur basin (Northwest Mongolia). International Review of Hydrobiology, 90: 580-595. DOI: 10.1002/iroh.200410782

FREY, D.G. 1982. Questions concerning cosmopolitanism in Cladocera. Archiv für Hydrobiologie, 93: 484-502.

GRILLAS, P, P. GAUTHIER, N. YAVERCOVSKI \& C. PERENNOU C. 2004. Mediterranean Temporary Pools. Station biologique de la Tour du Valat.

GUINDON, S. \& O GASCUEL. 2003. A simple, fast, and accurate algorithm to estimate large phylogenies by maximum likelihood. Systematic Biology, 52: 696-704.

HINDMARCH, C. \& J. KIRBY, 2002. Corridors for Birds within a Pan-European Ecological Network. Nature and Environment 123. Council of Europe, Strasbourg, France.

INCAGNONE, G., F. MARRONE, R. BARONE, L. ROBBA \& L. NASELLI-FLORES. 2015. How do freshwater organisms cross the "dry ocean"? A review on passive dispersal and colonization processes with a special focus on temporary ponds. Hydrobiologia, 750: 103-123. DOI: 10.1007/s10750-014-2110-3

JAUME, D. 1989-1990. Calanoides (Crustacea: Copepoda) de les aigües continentals Baleàriques. Bolleti de la Societat d'Història Natural de les Balears, 33: 207-219.

JERSABEK, C.D., A. BRANCELJ, F. STOCH \& R. SCHABETSBERGER. 2001. Distribution and ecology of copepods in mountainous regions of the Eastern Alps. Hydrobiologia, 453/454: 309-324. DOI: 10.1023/A:1013113327674

KAPPAS, I., G. MURA, D. SYNEFIARIDOU, F. MARRONE, G. ALFONSO, M. ALONSO \& T.J. ABATZOPOULOS. 2017. Molecular and morphological data suggest weak phylogeographic structure in the fairy shrimp Streptocephalus torvicornis (Branchiopoda, Anostraca). Hydrobiologia, 801: 21-32. DOI: 10.1007/s10750-017-3203-6

KARAGIANNI, A., G. STAMOU, M. KATSIAPI, P. POLYKARPOU, G. DÖRFLINGER \& E. MICHALOUDI. Zooplankton communities in Mediterranean temporary lakes: the case of saline lakes in Cyprus. Annales de Limnologie - International Journal of Limnology, 54: 14. DOI: 10.1051/limn/2018007

KARAOUZAS, I., E. DIMITRIOU, A. LAMPOU \& E. COLOMBARI. 2015. Seasonal and spatial patterns of macroinvertebrate assemblages and environmental conditions in Mediterranean temporary ponds in Greece. Limnology, 16: 41-53. DOI: 10.1007/s10201-014-0437-0

KETMAIER, V., F. MARRONE, G. ALFONSO, K. PAULUS \& A. WIEMANN. 2012. Mitochondrial DNA regionalism and historical demography in the extant populations of Chirocephalus kerkyrensis (Branchiopoda: Anostraca). PLoS ONE, 7: e30082. DOI: 10.1371/journal.pone.0030082

KIEFER, F. 1928. Beiträge zur Copepodenkunde (XI). Zoologischer Anzeiger, 79: 244-250.

KIEFER, F. 1971. Revision der bacillifer-Gruppe der Gattung Arctodiaptomus Kiefer. Memorie dell'Istituto Italiano di Idrobiologia, 27: 113-267.

KIEFER, F. 1978. Das Zooplankton der Binnengewässer. Freilebende Copepoda. Die Binnengewässer, Band 26 Teil 2. E. Schweizerbart'sche Verlagbuchhandlung, Stuttgart.

KLIE, W. 1941. Süsswasserostracoden aus Südosteuropa. Zoologischer Anzeiger, 133: 233-244.

KOTOV, A.A. \& M. ALONSO. 2010. Two new species of Leydigia Kurz, 1875 (Chydoridae, Cladocera) from Spain. Zootaxa, 2673: 39-55.

KUMAR, S., G. STECHER \& K. TAMURA. 2016. MEGA7: Molecular evolutionary genetics Analysis Version 7.0 for bigger datasets. Molecular Biology and Evolution, 33: 1870-1874. DOI: 10.1093/molbev/msw05

LANFEAR, R., B. CALCOTT, S.Y.W. HO \& S. GUINDON. 2012. Partition Finder: combined selection of partitioning schemes and substitution models for phylogenetic analyses. Molecular Biology and Evolution, 29: 1695-1701. DOI: $10.1093 / \mathrm{molbev} / \mathrm{mss} 020$.

LANFRANCO, S. 2001. A review of the branchiopod fauna of the Maltese islands (Crustacea: Branchiopoda). The Central Mediterranean Naturalist, 3: 109 - 114. 
LINDBERG, K. 1955. Notes sur les grottes de l'ile de Créte. Fragmenta Balcanica, 1(19): 165-174.

LINDBERG, K. 1956. Cyclopides (Crust. Cop.) de Crète, avec une liste de crustacés divers recueillis dans le lac de Kourna. Acta Musei Macedonici Scientiarum Naturalium Skopje, 5(5): 97-120.

MARINCEK, M. \& B. PETROV. 1995. Contribution to the taxonomy of species of the diaphanus group within the genus Chirocephalus Prevost, 1803 (Anostraca, Crustacea). Hydrobiologia, 298: 233-237. DOI: 10.1007/BF00033816

MARRONE, F., R. BARONE, \& L. NASELLI-FLORES. 2005. Cladocera (Branchiopoda: Anomopoda, Ctenopoda and Onychopoda) from Sicilian inland waters: an updated inventory. Crustaceana, 78: 1025-1039. DOI: $10.1163 / 156854005775361043$.

MARRONE, F. \& G. MURA. 2006. Updated status of Anostraca, Notostraca and Spinicaudata (Crustacea Branchiopoda) in Sicily (Italy): review and new records. Naturalista Siciliano, 30: 3-19.

MARRONE, F., G. CASTELLI, R. BARONE \& L. NASELLI-FLORES. 2006a. Ecology and distribution of Calanoid Copepods in Sicilian inland waters (Italy). Verhandlungen Internationale Vereinigung für Theoretische und Angewandte Limnologie, 29: 2150-2156. DOI: 10.1080/03680770.2006.11903072

MARRONE, F., R. BARONE \& L. NASELLI-FLORES. 2006b. Ecological characterization and cladocerans, calanoid copepods and large branchiopods of temporary ponds in a Mediterranean island (Sicily, Southern Italy). Chemistry and Ecology, 22: 181-190. DOI: 10.1080/02757540600557827

MARRONE, F., G. CASTELLI \& L. NASELLI-FLORES. 2009. Sicilian Temporary Ponds: an overview on the composition and affinities of their crustacean biota. In: Fraga I Argiumbau, P. (ed.) International Conference on Mediterranean Temporary Ponds. Proceedings \& Abstracts. Consell Insular de Menorca. Recerca,14. Maó, Menorca. pp. 189-202. ISBN: 978-84-9571-72-3.

MARRONE, F., S. LO BRUTTO \& M. ARCU-
LEO. 2010. Molecular evidence for the presence of cryptic evolutionary lineages in the freshwater copepod genus Hemidiaptomus G.O. Sars, 1903 (Calanoida, Diaptomidae). Hydrobiologia, 644: 115-125. DOI: 10.1007/ s10750-010-0101-6

MARRONE, F., S. LO BRUTTO, A.K. HUNDSDOERFER \& M. ARCULEO. 2013. Overlooked cryptic endemism in copepods: systematics and natural history of the calanoid subgenus Occidodiaptomus Borutzky 1991 (Copepoda, Calanoida, Diaptomidae). Molecular Phylogenetics and Evolution, 66: 190-202. DOI: 10.1016/j.ympev.2012.09.016

MARRONE, F., A. PETRUSEK, G. ALFONSO $\&$ M. ARCULEO. 2014. The diaptomid fauna of Israel (Copepoda, Calanoida, Diaptomidae), with notes on the systematics of Arctodiaptomus similis s.1. (Baird, 1859). Zoological Studies, 53: 74. DOI: 10.1186/s40555-014-0074-7

MARRONE, F., M. ALONSO, V. PIERI, C. AUGUGLIARO \& F. STOCH. 2015. The crustacean fauna of Bayan Onjuul area (Tôv Province, Mongolia) (Crustacea: Branchiopoda, Copepoda, Ostracoda). North-Western Journal of Zoology, 11: 288-295.

MARRONE, F., G. ALFONSO, L. NASELLI-FLORES \& F. STOCH. 2017. Diversity patterns and biogeography of Diaptomidae (Copepoda, Calanoida) in the Western Palearctic. Hydrobiologia, 800: 45-60. DOI: 10.1007/s10750-017-3216-1.

MAZZINI, I., E. GLIOZZI, G. ROSSETTI \& V. PIERI. 2014. A multidisciplinary contribution to the "Ilyocypris puzzle". International Review of Hydrobiology, 99: 1-14. DOI: 10.1002/iroh.201301729

MEISCH, C. 2000. Freshwater Ostracoda of Western and Central Europe. Spektrum Akademischer Verlag, Heidelberg, Berlin.

MEYBECK, M. 1995. Global distribution of lakes, p. 1-35. In A. Lerman, D. M. Imboden and J. R. Gat [eds.], Physics and chemistry of lakes. Springer-Verlag.

MIRACLE, M.R. 1982. Biogeography of the freshwater zooplanktonic communities of Spain. Journal of Biogeography, 9: 455-467.

MORENO, E., J. M. CONDE-PORCUNA \& A. GÓMEZ. 2017. Barcoding rotifer biodiversity 
in Mediterranean ponds using diapausing egg banks. Ecology and Evolution, 7: 4855-4867. DOI: $10.1002 /$ ece 3.2986

MURA, G. \& N. HADJSTEPHANOU. 1987. First records of Branchinella spinosa Milne-Edwards (Crustacea, Anostraca) in Cyprus. Rivista di Idrobiologia, 26: 1-3.

NYLANDER, J.A.A. 2004. MrModeltest 2. Program Distributed by the Author. Evolutionary Biology Centre, Uppsala University

PESCE, G. L. \& D. MAGGI. 1981. Cyclopoides et calanoïdes dese aux phréatiques de la Grèce meridionale et insulaire (Crustacea: Copepoda). Ecologia Mediterranea 7(1): 163-182.

PESCE, G. L. \& D. MAGGI. 1983. Ricerche faunistiche in acque sotterranee freatiche della Grecia Meridionale ed insulare e stato attuale delle conoscenze sulla stigofauna di Grecia. Natura, 74: 15-73.

PESTA, O. 1921. Kritische Revision der Branchipodidensammlung des Wiener naturhistorischen Staatsmuseums. Annalen des Naturhistorischen Museums in Wien, 34: 80-98.

PETKOVSKI, T.K. 1983. Calanoides-Calanoida (Crustacea-Copepoda). Faune de Macedonie, 5, Musée Histoire Naturelle de Macedonie, Skopje, Macedonia.

PETKOWSKI, T., B. SCHARF \& D. KEYSER. 2000. New and little known Ostracods of the genus Heterocypris (Crustacea, Ostracoda) from the Balkan Peninsula. Limnologica, 30: 45-57

PIERI, V., K. MARTENS, L. NASELLI-FLORES, F. MARRONE \& G. ROSSETTI. 2006. Distribution of recent ostracods in inland waters of Sicily (Southern Italy). Journal of Limnology, 65: 1-8. DOI: 10.4081/ jlimnol.2006.1

PRETUS, J. L. 1990. A commented check-list of the Balearic Branchiopoda (Crustacea). Limnetica, 6: 157-164.

RANGA REDDY, Y. 1994. Copepoda: Calanoida: Diaptomidae. Key to the genera Heliodiaptomus, Allodiaptomus, Neodiaptomus, Phyllodiaptomus, Eodiaptomus, Arctodiaptomus and Sinodiaptomus. Guides to the identification of the Microinvertebrates of the Continental Waters of the World. SPB Academic Publishing, The Hague.
RENIERS, J., B. VANSCHOENWINKEL, N. RABET \& L. BRENDONCK. 2013. Mitochondrial gene trees support persistence of cold tolerant fairy shrimp throughout the Pleistocene glaciations in both southern and more northerly refugia. Hydrobiologia, 714: 155-167. DOI: 10.1007/s10750-013-1533-6

RIVAS-MARTÍNEZ, S., A. PENAS \& T.E. DÍAZ. 2004. Bioclimatic \& Biogeographic Maps of Europe. (available at: http://www. globalbioclimatics.org/form/maps.htm)

RONQUIST, F., M. TESLENKO, P. VAN DER MARK, D.L. AYRES, A. DARLING, S. HÖHNA, B. LARGET, L. LIU, M.A. SUCHARD \& J.P. HUELSENBECK. 2012. MrBayes v. 3.2: Efficient Bayesian phylogenetic inference and model choice across a large model space. Systematic Biology, 61: 539-542. DOI: $10.1093 /$ sysbio/sys029.

RUFFO, S. \& F. STOCH (Eds). 2005. Checklist e distribuzione della fauna. Memorie del Museo Civico di Storia Naturale di Verona, 2 serie, Sezione Scienze della Vita, 16: 1-307.

SAHUQUILLO, M. \& M.R. MIRACLE. 2013. The role of historic and climatic factors in the distribution of crustacean communities in Iberian Mediterranean ponds. Freshwater Biology, 58: 1251-1266. DOI: 10.1111/fwb.12124

SINEV, A.Y., M. ALONSO, M.R. MIRACLE \& M. SAHUQUILLO. 2012: The West Mediterranean Alona azorica Frenzel \& Alonso, 1988 (Cladocera: Anomopoda: Chydoridae) is composed of two species. Zootaxa, 3276: 51-68.

STELLA, E. 1984. Fauna d'Italia, Crustacea. Copepoda: Calanoida. Calderini, Bologna, Italia.

STEPHANIDES, T. 1948. A survey of the freshwater biology of Corfu and of certain other regions of Greece. Praktika of the Hellenic Hydrobiological Institute, 2: 1-263.

STOCH, F., M. KORN, S. TURKI, L. NASELLI-FLORES \& F. MARRONE. 2016. The role of spatial environmental factors as determinants of large branchiopod distribution in Tunisian temporary waters. Hydrobiologia, 782: 37.51. DOI: 10.1007/s10750-015-2637-y STOICESCU, A. 1992. Chirocephalus diaphanus romanicus n. ssp. (Phyllopoda, Anostraca). Revue Roumaine de Biologie, Série de 
Biologie Animale, 37: 3-12.

THOMPSON, J.D., T.J. GIBSON, F. PLEWNIAK, F. JEANMOUGIN \& D.G. HIGGINS. 1997. The ClustalX windows interface: flexible strategies for multiple sequence alignment aided by quality analysis tools. Nucleic Acids Research, 24: 4876-4882.

TZIORTZIS, I., S. ZOGARIS, A. PAPATHEODOULOU \& F. MARRONE. 2014. First record of the Tadpole Shrimp Triops cancriformis (Branchiopoda, Notostraca) in Cyprus. Limnetica, 33: 341-348.

VAN DAMME, K. \& H.J. DUMONT. 2010. Cladocera of the Lençóis Maranhenses (NE Brazil): faunal composition and a reappraisal of Sars' Method. Brazilian Journal of Biology, 70: 755-779.

WHITTAKER, R.J., M.B. ARAÚJO, P. JEPSON, R.J. LADLE, J.E.M. WATSON \& K.J. WILLIS. 2005. Conservation Biogeogra- phy: assessment and prospect. Diversity and Distributions, 11: 3-23. DOI: 10.1111/j.13669516.2005.00143.x

ZAMORA, L., F. MEZQUITA \& J. LL. PRETUS. 2005. The nonmarine ostracod fauna of the Balearic Islands. Berliner Paläobiologische Abhandlungen, 6: 133.

ZACHARIAS, I. \& M. ZAMPARAS. 2010. Mediterranean temporary ponds. A disappearing ecosystem. Biodiversity and Conservation, 19: 3827-3834. DOI: 10.1007/s10531010-9933-7

ZARATTINI, P., G. MURA \& V. KETMAIER. 2013. Intra-specific variability in the thirteen known populations of the fairy shrimp Chirocephalus ruffoi (Crustacea: Anostraca): resting egg morphometrics and mitochondrial DNA reveal decoupled patterns of deep divergence. Hydrobiologia, 713: 19-34. DOI: 10.1007/s10750-013-1487-8.

Con el apoyo de: 